\title{
Networking of Engineering Schools in Region VI: Input to Development of Linkages
}

\author{
Annie V. Reyes, Braulio A. Reyes \\ Capiz State University Main Campus, Roxas City, Philippines
}

\begin{abstract}
The study was conducted to determine the networking programs of engineering schools, the areas covered, the extent of coverage of networking existing in the region, and the success level of networking. Likewise, the study sought to determine the significant differences in the networking programs, areas covered, extent of coverage, and success level when respondent schools are classified into type of school and student population. Findings of the study showed that the networking programs of engineering schools are information sharing, research and development (R\&D), skills learning, joint extension projects, technical assistance, and on-the-job training (OJT). The areas covered are instruction, community extension, library, research, human resource development (HRD), and production. The coverage of networking is extensive in the areas of research and instruction. Networking of engineering schools is of "Average" success. There was a significant difference in the networking programs when the respondent schools were categorized into student population.
\end{abstract}

Keywords: networking, engineering schools, engineering, networking programs, Region VI

\section{Introduction}

In today's globally competitive and fast changing environment, new technologies, products, skills, and services also become very complex, thereby, creating new challenges for universities and colleges in making education works. Universities need to interact with one another and with other organizations and agencies in order to be relevant and progressive, and most importantly, to cut cost and save money.

Networking and linkages allow an institution to undertake what is beyond its unaided competence, to boost student faculty opportunities, to conserve resources, and to facilitate access to knowledge.

In the field of engineering, networking is very much applicable since this course involves different outputs, processes, and skills. Engineering schools need to collaborate with one another and with industries in sharing knowledge, enhancing research and development (R\&D), patenting discoveries and innovations, and commercializing products. Likewise, networking could be a generative force for technology transfer and technology utilization.

Networking may likewise provide financial support for the university in the field of research, which could lead to students' exposure to research and provide university researchers a chance to work on an intellectually challenging programs in the field of engineering and technology.

The main objective of the study is to determine the networking activities of engineering schools in

Annie V. Reyes, Ph.D., Professor V, Capiz State University Main Campus.

Braulio A. Reyes, Ed.D., Professor IV, College of Engineering and Architecture, Capiz State University Main Campus. 
Western Visayas (Region VI) of the Philippines. Its specific objectives are:

1. To determine the networking programs of engineering schools as a whole and when the respondent schools are classified into type of school and student population;

2. To find out the areas covered by engineering networking in Region VI as a whole and when the respondent schools are classified into type of school and student population;

3. To measure the extent of coverage of networking in Region VI;

4. To measure the success level of networking of engineering schools in Region VI;

5. To find out significant differences in the networking programs, areas covered by networking, extent of coverage, and success level when the respondent schools are categorized into type of school and student population.

\section{Related Literature and Studies}

Hamdan, Yusof, Omar, Abdullah, Nasrudin, and Abullah (2011) conducted a study to explore the formation of linkages between the higher education institution (University Technology MARA) and industries located in the Klang Valley Region of Malaysia. Based on the findings of the study, the specific reasons of industry for collaborating with university research centers are: (a) lack of in-house R\&D; (b) shortening product life-cycle; (c) cutback in R\&D budgets; and (d) changing nature of research priorities. On one hand, university research centers also want to collaborate with industries as they increasingly need find new ways of generating income as the government intents to reduce $R \& D$ fund. It was also discovered that firms enter into university-industry relationships to gain access to students as potential future employees and to aid on product development.

The study showed that of the types of linkages existing between the university and industry, university student internship with 53\% got the highest percentage. Even though there were 19\% who did not respond, $81 \%$ indicated that they have interaction with the academia in terms of staff industrial training, interaction by attending a conference and seminar, as well as engaging academia in projects, consultancy, and joint research. Linkages, such as use and licensing of university held patents, use of incubator and laboratory facilities of university, exchange of information and knowledge, and engagement in science parks, have not embedded in the relationship of both university and industry. Findings also showed that industries can enhance their roles in the region's economic development and had realized the importance of engaging R\&D with the university. Sixty-nine percent agreed that both university and industry should have strong linkages in R\&D activities (Hamdan et al., 2011).

The study further revealed that the main constraints the industries perceived to have limited their collaborations were time, manpower, financial support, and communications. Overall level of constraints in the university-industry linkages were at a moderate level skewed to scale of "Little extent". On the other hand, for trading companies, they were having constraints at a great extent on time, manpower, and financial support. For firms of information technology, the level of constraints was at a low level with "Little extent" to "Not at all" in terms of financial support, time, and manpower. The same pattern also exists for construction and services firms. Therefore, it can be concluded that industries were not entirely having very significant constraints to have a strong linkage with the university (Hamdan et al., 2011).

The study revealed that, to enhance the relationship of both industry and university, jointly organizing meetings, talks, and communication received the highest mean score to be on the slightly effective ways to 
collaborate, followed by industrial internship in the academic curriculum, encouraging industrial visits by students, and encouraging industrial representative in university committee. Setting up industrial parks closer to universities, received tax concessions collaborating with university, and establishing a mechanism to link universities with industries received a lower mean rank, which might indicate that industries have not really foreseen how they can participate when the setup of those companies are under small and medium enterprises. Somehow, in order for the linkages to materialize, the work of the university can be publicize to industries and the academicians can play their roles by being a representative in industrial committees, chambers, and board of organizations (Hamdan et al., 2011).

As for the potentials of university-industry linkages, the study suggested to include industrial internship in the curricula, encourage industrial visits by students, encourage regular industrial visits by academics, improve laboratory facilities and other infrastructure at universities, involve staff from industry in teaching programs, set up a mechanism to link universities with industries, publicize university activities relevant to industry, jointly (university and industry) organize informal meetings, talks, and communications, government tax concessions for companies collaborating with universities, set up industrial parks closer to universities, encourage academic representative in industrial committees/chambers/boards, and encourage industry representative in university committees (Hamdan et al., 2011).

According to Tansinin (2004), the nature/type of university-industry partnership maybe classified as: (a) contractual R\&D; (b) support of an industry's R\&D activities; (c) licensing and transfer of technology; (d) $R \& D$ joint ventures and support for spin-off companies; (e) consultancy by university faculty; (f) funding post-graduate or graduate students; and (g) on-the-job training (OJT) of students in industry.

Based on the findings of the study, support from industry is still small compared with other countries as firms look at research activity as an expense and not as insurance for new or better quality product and high productivity. Most of the companies have quality control unit but not in the real sense of R\&D of a fully equipped laboratory that would allow researchers to undertake research to improve their products, process, and materials. However, research activities for marketing and other social research are undertaken with full funding support (Tansinin, 2004).

Findings of the study further showed that consultancy of faculty members is allowed by the university, provided the task of teaching is not neglected. Consultancy is a means to strengthen the capability of faculty members. However, before entering into a consultancy, the faculty, university, and researcher should have a memorandum of understanding to be transparent and avoid any conflict of interest for all the parties (Tansinin, 2004).

Problems confronting the university-industry partnership as identified in Edralin's (2001) study were:

1. Administrative and financial support of partner agencies, particularly the bureaucratic requirements and processes (e.g., red tape in the evaluation of proposals, project delays, limited budget, etc.);

2. Problems concerning faculties and the staff members particularly lack of full-time researchers, scientists, and experts in statistics, and lack of faculty involvement due to teaching loads, lack of faculty with research skills, and experience;

3. Lack of administrative and financial support from the school;

4. Problems concerning the supervision and implementation of projects by the school.

\section{Theoretical Background}

Granovetter's Strength of Weak Ties (SWT) theory was used in the study. The theory has for its first 
premise that the stronger the tie between two people, the more likely that their social worlds will over-lap and that they will have ties with the same third party, a kind of transitivity. The theory asserted that individuals' acquaintances (weak ties) are less likely to be socially involved with one another than are their close friends (strong ties). Thus, the set of people made up of any individual and his/her acquaintances comprises a low-density network whereas the set consisting of the same individual and his/her close friends will be densely knit.

Granovetter illustrated his theory through giving an example. In his example, Ego has a collection of close friends, most of whom are in touch with one another-a densely knit clump of social structure. In addition, Ego will have a collection of acquaintances, few of whom know one another. Each of these acquaintances, however, is likely to have close friends in his own right and therefore enmeshed in a closely knit clump of social structure, but one different from Ego's. The weak tie between Ego and his acquaintance, therefore, becomes not merely a trivial acquaintance tie but rather a crucial bridge between the two densely knit clumps of close friends. These clumps would not, be connected to one another at all were it not for the existence of weak ties. It follows, then, that individuals with few weak ties will be deprived of information from distant parts of the social system and will be confined to the provincial news and views of their close friends. This deprivation will not only insulate them from the latest ideas and fashions but may put them in a disadvantaged position in the labor market, where advancement can be depended or on knowing about appropriate job openings at just the right time. The macroscopic side of this communications argument is that social systems lacking in weak ties will be fragmented and incoherent. New ideas will spread slowly, scientific endeavors will be handicapped, and subgroups separated by race, ethnicity, geography, or other characteristics will have difficulty reaching a modus vivendi (Granovetter, 1973).

Granovetter used this theory to explain further why people often get or at least hear about jobs through acquaintances rather than close friends. In this sense, the theory is one of individual social capital, where people with more weak ties (i.e., more social capital) are more successful.

Granovetter also applied the theory at the group level, arguing that communities with many strong ties have pockets of strong local cohesion but weak global cohesion. In contrast, communities with many weak ties have weak local cohesion but strong global cohesion. Thus, a community's diffuse, weak-tie structure constitutes group-level social capital that enables the group to work together to achieve goals, such as mobilizing resources and organizing community action to respond to an outside threat.

\section{Conceptual Framework}

Based on Granovetter's SWT theory, the present study looked into networking and linkages of engineering schools in Region VI in terms of the networking programs, the areas of their programs, extent of coverage, and success level of networking programs, and its impact on study conditions, study provisions, and school activities.

The paradigm of the study shows that engineering schools offering different engineering courses, as state universities and colleges or private colleges or universities, with varying student population, can network with other educational institutions, government organizations or non-government organizations (NGOs), and business establishment to attain common goals, to enhance quality education, and to improve the national economy. It is the objective of the study to assess networking among engineering schools in Region VI by determining the different networking programs, the areas covered by networking, the coverage of networking, and the success level of networking. The schematic diagram is shown in Figure 1. 
Independent Variable

\begin{tabular}{|l|l|}
\hline \begin{tabular}{l|l|}
\hline Type of School \\
Public \\
Private
\end{tabular} & \begin{tabular}{l}
\multicolumn{1}{|c|}{ Status of Networking } \\
1. Networking programs \\
2. Areas
\end{tabular} \\
\cline { 2 - 3 } $\begin{array}{l}\text { Student Population } \\
\text { Big } \\
\text { Small }\end{array}$ & 4. Success level of networking \\
\hline
\end{tabular}

Figure 1. Schematic diagram of the study.

\section{Methodology}

This is a census study for a small population since it covers 17 engineering school members of the Council of Engineering and Architecture Education of Western Visayas (CEAS-WV) during the academic year 2012-2013. There were 102 individual respondents who were selected by means of purposive or deliberate sampling strategy since they have first-hand information and have direct knowledge on networking activities of their respective school.

Table 1 shows the profile of the 17 engineering schools distributed into type of school and student population. The type of school was classified into public and private schools. It shows that seven of the schools (41.2\%) are identified as public schools while $10(58.8 \%)$ are said to be private schools. Out of 17 schools, 12 (70.6\%) are considered small schools with an enrollment between 89 and 644, and only five (29.4\%) are big schools with a total enrollment between 645 and 1,200.

Table 1

Data of the Respondent Schools

\begin{tabular}{llc}
\hline & & Number of schools \\
\hline \multirow{2}{*}{ Type of school } & Public & 7 \\
& Private & 10 \\
\hline \multirow{2}{*}{ Student population } & Big & 5 \\
& Small & 12 \\
\hline
\end{tabular}

The data in the study were gathered using the questionnaire adapted from Villanueva's (1997) and interviews with the deans, faculty, and staff of the respondent schools. The interview guide covered questions on the percentage attainment of the project's objectives and probable reasons of the variance in planned and actual networking activities.

Since the sample was selected through the purposive sampling technique, a computer Statistical Package for Social Sciences (SPSS) program on non-parametric tools was used to test the significant differences in the selected variables among the respondent engineering schools.

The significance of differences in the networking programs, areas covered, and the coverage of networking among schools were calculated using the Kolmogorov-Smirnov (K-S) test for two sample cases due to zero cell frequencies in some categories. 
The descriptions of the networking programs, areas covered, coverage, and success of networking in Region VI were based on the results of the analysis using mean, range, percentage, and rank.

The coverage of networking, as indicated by the number of schools, government organizations or NGOs, business enterprises, local government units (LGUs), and professional organizations that linked with the engineering schools, was interpreted using the criteria shown in Table 2.

Table 2

Coverage of Networking

\begin{tabular}{ll}
\hline Number of schools, organizations, LGUs, business enterprises, and professional organizations involved & Score points \\
\hline 5 or more & 3 \\
$3-4$ & 2 \\
$1-2$ & 1 \\
\hline Scale of interval & Description \\
\hline $2.40-3.00$ & Great extent \\
$1.70-2.39$ & Some extent \\
$1.00-1.69$ & Little extent \\
\hline
\end{tabular}

The interpretations of success of networking in engineering schools are shown in Table 3.

Table 3

Success of Networking

\begin{tabular}{llll}
\hline & & Success level description & Score points \\
\hline \multirow{3}{*}{ Number of years } & 5 or more & High & 3 \\
& $3-4$ & Average & 2 \\
\hline \multirow{3}{*}{ Extent of objective achievement } & $1-2$ & Low & 1 \\
\hline & $75 \%-100 \%-74 \%$ & High & 3 \\
& $49 \%$ and below & Average & 2 \\
Number of areas & 5 or more & Low & 1 \\
\hline \multirow{3}{*}{ Number of projects } & $3-4$ & High & 3 \\
& $1-2$ & Average & 2 \\
& 5 or more & Low & 1 \\
\hline
\end{tabular}

An engineering school having networking activities for five years or more scores 3 points ("High" success level) while networking for three to four years scores 2 points ("Average"). Collaboration for one to two years scores 1 ("Low" success level).

The extent of objective achievement was determined by assigning score points to the percentage. Attainment between $75 \%-100 \%$ was given 3 points and described as a "High" success level. On the other hand, attainment between $74 \%-50 \%$ was assigned 2 points or "Average" success, and attainment between $49 \%$ and below was assigned 1 point and categorized as "Low" level of networking success.

Engineering schools covering five or more networking areas were scored 3 points ("High"), schools with three to four areas are "Average" with 2 points, and those with one to two areas had "Low" success rating with 1 score point. 
An area with five or more networking projects earned 3 points and was given a "High" success rating. An area with three to four networking projects was given 2 points and was described to be of "Average" success, and an area having one to two projects gets 1 point or a "Low" success level.

A composite rating of the average score points was used to determine the overall success of networking engineering schools in Region VI. A rating of 10-12 was described as "Very high" while that 8-9 was "High". A rating of 6-7 was "Average" and a rating of 4-5 was described as "Low" (see Table 4).

Table 4

Composite Success Rating

\begin{tabular}{ll}
\hline Points & Qualitative description \\
\hline $10-12$ & Very high \\
$8-9$ & High \\
$6-7$ & Average \\
$4-5$ & Low \\
\hline
\end{tabular}

\section{Results and Discussion}

\section{Networking Programs of Engineering Schools as a Whole and When Classified According to Type of School and Student Population}

A respondent school usually has a networking project that covers more than one kind of networking program. For example, an engineering school has research projects in collaboration with a government agency. The collaboration is in the nature of: (a) technical assistance; (b) financial grant; and (c) sharing of laboratory equipment, hence, these networking projects involved three networking programs.

Table 5 gives the number of networking projects involved in each specific networking program. The three top ranking programs are: (a) information sharing; (b) R\&D; and (c) joint extension project. Each program was composed of 64,46 , and 43 projects respectively. The three networking programs at the tail-end are: (a) sharing of library resources; (b) financial assistance; and (c) faculty exchange.

Result of the study did not change the findings of the study of Villanueva (1997), which reported that information sharing is the topmost networking program in higher education institutions in Region VI and sharing of library resources and faculty exchange at the bottom.

In Hamdan et al.'s (2011) study, $81 \%$ of the industry respondents indicated that they have linkages with the academy in terms of staff industrial training, interaction by attending a conference and seminar, as well as engaging the academy in projects, consultancy, and joint research. Findings of the study further revealed that from the listing of various possible linkages, the highest percentage appeared to be a university student internship with $53 \%$.

Table 5 likewise reveals the different networking programs by public and private engineering schools in Region VI. The results show that networking projects having programs on information sharing was the topmost among networking programs regardless whether the school is public or private. This could be the result of meetings, symposia, fora, conventions, and gatherings of different engineering professional organizations. R\&D ranked second in public schools and private schools respectively.

The study further showed that networking programs on R\&D comes strong in public engineering schools, this is because of the four quadro dimensional thrusts of the state universities and colleges where R\&D was given priority together with joint extension projects which ranked third. On one hand, networking 
programs of private engineering schools were on skill learning and technical assistance. Joint extension projects only ranked fifth.

Table 5

Distribution of Networking Projects by Networking Programs

\begin{tabular}{|c|c|c|c|c|c|c|c|c|c|c|}
\hline \multirow{2}{*}{ Networking program } & \multirow{2}{*}{$\begin{array}{l}\text { Freq. of } \\
\text { projects }\end{array}$} & \multirow{2}{*}{$\begin{array}{l}\text { Total } \\
\text { rank }\end{array}$} & \multicolumn{4}{|c|}{ Type of school } & \multicolumn{4}{|c|}{ Student population } \\
\hline & & & Rank & Public & Rank & Private & Rank & Small & Rank & Big \\
\hline Information sharing & 64 & 1 & 1 & 27 & 1 & 37 & 1 & 29 & 1 & 29 \\
\hline $\mathrm{R} \& \mathrm{D}$ & 46 & 2 & 2 & 20 & 2 & 26 & 3.5 & 22 & 3.5 & 24 \\
\hline Skills learning & 45 & 5 & 3 & 15 & 6 & 30 & 2 & 26 & 2 & 19 \\
\hline Joint extension projects & 43 & 3 & 4.5 & 18 & 3 & 25 & 5 & 20 & 5 & 23 \\
\hline Technical assistance & 43 & 4 & 4.5 & 17 & 4 & 26 & 3.5 & 22 & 3 & 21 \\
\hline OJT & 32 & 7 & 6 & 11 & 9 & 21 & 6 & 15 & 6 & 17 \\
\hline Shared laboratory equipment & 29 & 6 & 7 & 15 & 6 & 15 & 7 & 11 & 8.5 & 18 \\
\hline In-service training for teachers & 26 & 8 & 8.5 & 15 & 6 & 11 & 11.5 & 11 & 8.5 & 15 \\
\hline Plant visits for students & 26 & 11 & 8.5 & 12 & 8 & 14 & 8.5 & 14 & 7 & 12 \\
\hline Sharing of library resources & 24 & 9 & 10 & 9 & 10 & 15 & 7 & 10 & 10 & 14 \\
\hline Scholarships & 16 & 10 & 11 & 5 & 11 & 11 & 11.5 & 3 & 13 & 13 \\
\hline Financial assistance & 13 & 12 & 12 & 0 & 14 & 13 & 10 & 6 & 11 & 7 \\
\hline Others & 10 & 13 & 13 & 2 & 12 & 8 & 13 & 6 & 11 & 4 \\
\hline Faculty exchange & 4 & 14 & 14 & 1 & 13 & 3 & 14 & 2 & 14 & 2 \\
\hline Total & 421 & - & - & 167 & - & 254 & - & 203 & - & 218 \\
\hline
\end{tabular}

As shown further in Table 5, the least networking projects were on faculty exchange, financial assistance, and scholarships regardless of type of school.

When classified according to student population, Table 5 reveals that information sharing ranked first whether the engineering school is big or small. For small schools, skill learning ranked second while R\&D and technical assistance ranked third. For big schools, ranked second is R\&D and ranked third is joint extension projects.

Results of the study further showed that there is a need to strengthen networking programs on faculty exchange, scholarships, and financial assistance. This further implies that engineering schools, whether big or small, should collaborate with government agencies, non-government agencies, business and industries, and other organizations for projects which have these networking programs.

Engineering schools in Region VI are expected to go into networking on areas that they urgently need and where their services are needed. It is then inferred from the results of this study that information sharing, R\&D, and joint extension projects are their priorities.

\section{Areas Covered by Networking}

Based on the literature on networking and thrust of some state colleges and universities, the researchers identified six areas into which collaboration efforts or linkages may be focused.

Among the 17 engineering schools in the region, the area on instruction rank first with a total frequency of 14 schools identified as having networking activities on this area, followed by community extension and library with 11 engineering schools each. Results further show that most engineering schools have linkages with other organizations/agencies in the areas of instruction, community extension, and library. It can be inferred that 
engineering schools in Region VI had prioritized these three areas for their networking activities and had given less attention to human resource development (HRD) and production.

Table 6 also reveals that there are six public and eight private engineering schools identified as having networking or collaboration in the area of instruction. This is followed by five public and six private schools in the areas of community extension and library. In the area of research, four schools of both public and private were in collaboration with other government/non-government agencies, other educational institutions, and industries to achieve common goals. The study shows that engineering schools, public or private, have weak networking activities in the areas of HRD and production.

Table 6

Areas Covered by Networking

\begin{tabular}{|c|c|c|c|c|c|c|c|c|c|c|}
\hline \multirow{2}{*}{ Areas of networking } & \multirow{2}{*}{$\begin{array}{l}\text { No. of } \\
\text { school }\end{array}$} & \multirow{2}{*}{ Rank } & \multicolumn{4}{|c|}{ Type of school } & \multicolumn{4}{|c|}{ Student population } \\
\hline & & & Public & Rank & Private & Rank & Small & Rank & Big & Rank \\
\hline Instruction & 14 & 1 & 6 & 1 & 8 & 1 & 10 & 1 & 4 & 2 \\
\hline Community extension & 11 & 2.5 & 5 & 3 & 6 & 2 & 7 & 3 & 4 & 2 \\
\hline Library & 11 & 2.5 & 5 & 2 & 6 & 3 & 8 & 2 & 3 & 4 \\
\hline Research & 8 & 4 & 4 & 4 & 4 & 4 & 4 & 4 & 4 & 2 \\
\hline HRD & 3 & 5 & 1 & 5 & 2 & 5 & 2 & 5.5 & 1 & 5 \\
\hline Production & 2 & 6 & 1 & 5 & 1 & 6 & 2 & 5.5 & 0 & 6 \\
\hline
\end{tabular}

In this study, a school is considered small if its population is 89-644 and considered big if its population is $645-1,200$. The study shows that 10 small schools and four big ones are engaged in networking in the area of instruction. In the area of community extension, there are seven small schools and four big schools, and in the area of library, there are eight small and three big schools.

It is noteworthy to know that no big schools are engaged in production. These big schools are private schools which could finance themselves from high tuition fees and miscellaneous fees of their students, hence, do not rely on production to support themselves.

\section{Coverage of Networking of Engineering Schools}

Table 7 reveals the different linkages of engineering schools in Region VI. It shows that in the area of research, the schools linked mostly with other schools and government organizations and agencies but have little linkages with business enterprises and professional organizations.

As a whole, engineering schools in Region VI are engaging in networking to a "Great extent" in the areas of research, instruction, and community extension. This result implies that schools, government organizations, business enterprises, LGUs, and professional organizations establish linkages in these four areas.

In the area of instruction, engineering schools have linkages with 37 business industries and 21 government organizations, but have only two linkages with LGUs. This is because included in the engineering curriculum are field trips and plant visits that require students to go to different industrial plants, facilities, factories, and other government owned and controlled corporations for the purpose of gaining first-hand information and experience. Added to these are the efforts of the different government agencies in granting seminars and conventions to update faculty engineers about the latest in engineering technology.

Majority of the linkages in the area of community extension are with the LGUs and with other schools, but not much with the business enterprises and professional organizations. 
Table 7

Coverage of Networking Programs by Area

\begin{tabular}{|c|c|c|c|c|c|c|c|c|c|c|c|c|}
\hline \multirow{3}{*}{$\begin{array}{l}\text { Linkages of different } \\
\text { schools }\end{array}$} & \multicolumn{12}{|c|}{ Frequency and score points per area } \\
\hline & \multicolumn{2}{|c|}{ Research } & \multicolumn{2}{|c|}{ Instruction } & \multicolumn{2}{|c|}{$\begin{array}{l}\text { Community } \\
\text { extension }\end{array}$} & \multicolumn{2}{|c|}{ HRD } & \multicolumn{2}{|c|}{ Production } & \multicolumn{2}{|c|}{ Library } \\
\hline & $F$ & Score & $F$ & Score & $F$ & Score & $F$ & Score & $F$ & Score & $F$ & Score \\
\hline Schools & 6 & 3 & 12 & 3 & 21 & 3 & 9 & 3 & 4 & 2 & 41 & 3 \\
\hline Government organizations & 5 & 3 & 21 & 3 & 8 & 3 & 8 & 3 & 10 & 3 & 2 & 1 \\
\hline NGOs & 5 & 3 & 5 & 3 & 15 & 3 & 1 & 1 & 2 & 1 & 3 & 2 \\
\hline Business enterprises & 3 & 2 & 37 & 3 & 2 & 1 & 4 & 2 & 8 & 3 & 0 & - \\
\hline LGUs & 6 & 3 & 2 & 1 & 22 & 3 & 0 & - & 2 & 1 & 4 & 2 \\
\hline Professional organizations & 3 & 2 & 14 & 3 & 7 & 3 & 10 & 5 & 5 & 3 & 8 & 3 \\
\hline Average score & - & 2.7 & - & 2.7 & - & 2.7 & - & 2.3 & - & 2.2 & - & 1.83 \\
\hline Description & \multicolumn{2}{|c|}{ Great extent } & \multicolumn{2}{|c|}{ Great extent } & \multicolumn{2}{|c|}{ Great extent } & \multicolumn{2}{|c|}{ Some extent } & \multicolumn{2}{|c|}{ Some extent } & \multicolumn{2}{|c|}{ Some extent } \\
\hline
\end{tabular}

There are linkages between engineering schools and professional organizations and among engineering schools in the area of HRD, as indicated in Table 7. However, there is none with LGUs and only one with NGOs.

As further shown in Table 7, there are 10 government organizations collaborating with engineering schools in the area of production. The involvement of government organizations in this area may have resulted from the efforts of the government in encouraging schools to generate income to support their necessary expenses and expenditures aside from the allotted budget they regularly receive.

Forty-one schools and eight professional organizations were found to collaborate with engineering schools in Region VI in the area of library. However, there is none with the business enterprises.

\section{Success of Networking Programs of Engineering Schools}

The success of networking of engineering schools in the region was determined by obtaining the composite rating based on: (a) the number of years an engineering school has linking projects with schools, government organizations, NGOs, business enterprises, LGUs, and professional organizations; (b) the extent of achievement of networking objectives; (c) the number of projects an area has; and (d) the number of networking areas covered by each respondent school in its networking activities

The overall result of the success level of networking of engineering schools is shown in Table 8. Of the 17 engineering schools in Region VI, only one got "Very high" success rating while five schools scored "High" success rating in their networking activities. Eleven engineering schools, however, posted an "Average" success rating.

So, an engineering school can only be in "Very high" success level if its networking activities have been going on for more than five years, covering at least five areas, and with more than five projects being undertaken. In like manner, a networking activity can only be considered very successful if its goals and objectives are $100 \%$ attained.

Overall results yield a composite rating of 7 which indicates an "Average" success of networking of engineering schools in Region VI. This may be due to lack of knowledge on the part of some administrators as to what linking agencies are available for networking activities. Also, some engineering schools cannot afford to share their laboratory equipment and facilities with other school due to lack of finances for repairs in case of breakdown and loss. Moreover, engineering schools tend to compete with each other, thus, sharing of resources and forging of mutual relationships became next to impossible. 
Table 8

Overall Success Rating of Respondent Schools

\begin{tabular}{|c|c|c|c|c|c|c|c|c|c|c|}
\hline \multirow{3}{*}{ Schools } & \multicolumn{8}{|c|}{ Success level } & \multirow{3}{*}{$\begin{array}{l}\text {-Composite } \\
\text {-rating }\end{array}$} & \multirow{3}{*}{ Description } \\
\hline & \multicolumn{2}{|r|}{$\mathrm{A}$} & \multicolumn{2}{|r|}{$\mathrm{B}$} & \multicolumn{2}{|r|}{$\mathrm{C}$} & \multicolumn{2}{|r|}{$\mathrm{D}$} & & \\
\hline & Score & Description & Score & Description & Score & Description & Score & Description & & \\
\hline 1 & 1 & Low & 3 & High & 1 & Low & 2 & Average & 7 & Average \\
\hline 2 & 3 & High & 3 & High & 1 & Low & 2 & Average & 9 & High \\
\hline 3 & 1 & Low & 3 & High & 1 & Low & 2 & Average & 7 & Average \\
\hline 4 & 2 & Average & 3 & High & 1 & Low & 2 & Average & 8 & High \\
\hline 5 & 2 & Average & 3 & High & 1 & Low & 1 & Low & 7 & Average \\
\hline 6 & 2 & Average & 3 & High & 1 & Low & 1 & Low & 7 & Average \\
\hline 7 & 1 & Low & 3 & High & 1 & Low & 1 & Low & 6 & Average \\
\hline 8 & 1 & Low & 3 & High & 1 & Low & 1 & Low & 6 & Average \\
\hline 9 & 1 & Low & 3 & High & 1 & Low & 1 & Low & 6 & Average \\
\hline 10 & 1 & Low & 3 & High & 1 & Low & 1 & Low & 6 & Average \\
\hline 11 & 1 & Low & 3 & High & 1 & Low & 1 & Low & 6 & Average \\
\hline 12 & 2 & Average & 3 & High & 1 & Low & 1 & Low & 7 & Average \\
\hline 13 & 1 & Low & 3 & High & 2 & Average & 1 & Low & 7 & Average \\
\hline 14 & 2 & Average & 3 & High & 1 & Low & 2 & Average & 8 & High \\
\hline 15 & 3 & High & 3 & High & 1 & Low & 2 & Average & 9 & High \\
\hline 16 & 1 & Low & 3 & High & 2 & Average & 2 & Average & 8 & High \\
\hline 17 & 3 & High & 3 & High & 1 & Low & 3 & High & 10 & Very high \\
\hline Mean & 2 & Average & 3 & High & 1 & Low & 1 & Low & 7 & Average \\
\hline
\end{tabular}

Notes. A $=$ The number of years an engineering school has linking projects with schools, government organizations, NGOs, business enterprises, LGUs, and professional organizations; $\mathrm{B}=$ The extent of achievement of networking objectives; $\mathrm{C}=$ The number of projects an area has; and $\mathrm{D}=$ The number of networking areas covered by each respondent school in its networking activities.

According to Edralin (2001), the university-industry partnership encountered difficulties due to problems concerning faculties and the staff members, particularly lack of full-time researchers, scientists, and experts in statistics, and lack of faculty involvement due to teaching loads, lack of faculty with research skills and experience, and lack of administrative and financial support from the school. Problems concerning the supervision and implementation of projects by the school were also seen to challenge the success of university-industry linkages in R\&D of research.

It may also be mentioned further that some of the industry sector are still in doubt of the capabilities of the local laboratories, thus the industries are consulting their mother company or just buy or have a foreign license for a particular technology (Edralin, 2001).

\section{Differences in Networking Programs, Areas Covered, Extent of Coverage, and Success Level When Categorized Into Type of School and Student Population}

Results of the study showed that there was a significant difference in the networking programs when the engineering schools were classified according to student population. The $p$-value of 0.022 is lesser than the set alpha of 0.05 level of significance under a two-tailed test, indicating a significant difference existed in the networking programs of small and big schools. This means that big schools have more networking programs than small schools (see Table 9). 
Table 9

Differences in Networking Programs

\begin{tabular}{|c|c|c|c|c|c|c|}
\hline & Variable & $N$ & Mean & $\mathrm{K}$-S $z$-value & $p$-value & Remarks \\
\hline \multirow{2}{*}{ Type of school } & Public & 7 & 23.86 & \multirow{2}{*}{0.580} & \multirow{2}{*}{0.890} & \multirow{2}{*}{ Not significant } \\
\hline & Private & 10 & 25.40 & & & \\
\hline \multirow{2}{*}{ Student population } & Small & 12 & 16.92 & \multirow{2}{*}{1.503} & \multirow{2}{*}{0.022} & \multirow{2}{*}{ Significant } \\
\hline & Big & 5 & 43.60 & & & \\
\hline
\end{tabular}

Findings of the study further showed that there were no significant differences in the areas covered, extent of coverage of networking programs, and composite rating of level of success of networking when the respondent schools were categorized into type of school and student population.

\section{Conclusions}

Based on the findings of the study, the researchers concluded that:

1. The networking programs of engineering schools in Region VI are mainly on information sharing, $R \& D$, skills learning, joint extension projects, technical assistance, and OJT;

2. The areas covered by networking of engineering schools in the region are instruction, community extension, library, research, HRD, and production;

3. The coverage of networking is extensive in the areas of research, instruction, and community extension. There are networking activities to "Some extent" in the areas of HRD, production, and library. Generally, networking of engineering schools is rated to "Great extent";

4. Networking of engineering schools in Region VI is of "Average" success;

5. There is a significant difference in the networking programs between small schools and big schools, hence, the null hypothesis is rejected;

6. There are no significant differences in the areas covered, coverage of networking existing in the region, and the composite rating of level of success of networking when the respondent schools were categorized into type of school and student population, hence, the null hypotheses are accepted.

\section{Recommendations}

The researchers recommend that members of the CEAS-WV through their administrators should maintain or intensify the on-going networking programs on R\&D, skills learning, joint extension project, technical assistance, and OJT. Networking on faculty exchange, financial assistance, scholarships, and sharing of library resources may also be explored. Engineering schools are also encouraged to form consortia of schools at the regional level for research and extension.

Administrators of engineering schools may take the initiative of establishing networking projects in any of the six areas with the following proposed networking guide: A school can gain support, be it financial or otherwise, by collaborating directly with business enterprises, government organizations and agencies, NGOs, LGUs, and professional organizations. In the same manner, an engineering school may also benefit when two or more of the linking agencies are coordinated with one another in giving support to the school in its networking project, i.e., multiple funding/expertise sources for a specific project.

To enhance the relationship of both industry and university, jointly organizing meetings and talks and communication is encouraged. Likewise, it is recommended to improve laboratory facilities and other 
infrastructure at universities, involve staff from industry in teaching programs, publicize university activities relevant to industry, government tax concessions for companies collaborating with universities, encourage academic representative in industrial committees/boards, and encourage industry representative in university committees.

\section{References}

De la Peňa, F. (2005). Study on the feasibility of establishing IP-related business development services hubs in ASEAN, Philippines. Retrieved from http://www.wipo.int/export/sites/www/uipc/en/.../doc/ui_partnership_ph.doc

Edralin, D. (2001). Higher education research papers (Vol. 1). Retrieved from http://www.ched.gov.ph/wp-content/uploads/.../ HE-Research-Papers-2001.pdf

Esham, M. (2008). Strategies to develop university-industry linkages in Sri Lanka. National Education Commision Sri Lanka Study Series. Retrieved from http://www.academia.edu/.../Strategies_to_Develop_University-Industry_Linka...

Granovetter, M. S. (1973). The strength of weak ties. American Journal of Sociology, 78(6), 1360-1380. Retrieved from https://sociology.stanford.edu/sites/default/files/publications/the_strength_of_weak_ties_and_exch_w-gans.pdf

Hamdan, H., Yusof, F., Omar, D., Abdullah, F., Nasrudin, N., \& Abullah, I. C. (2011). University-industrial linkages: Relationship towards economic growth and development in Malaysia. World Academy of Science, Engineering and Technology, 58, 785-792. Retrieved from http://connection.ebscohost.com/c/articles/88911858/university-industrial-linkages -relationship-towards-economic-growth-development-malaysia

Tansinin, L. (2004). Development of university-industry partnerships for the promotion of innovation and transfer of technology: Philippines. Commission on Higher Education. Retrieved from http://www.iccwbo.org/.../Development...technology-transfer /Technology-Tra...pdf

Villanueva, A. C. (1997). Networking in Western Visayas towards regional networking program (Unpublished doctorial dissertation, University of San Agustin Graduate School). 